\title{
Biological and chemical response of a grassland soil to burning
}

\author{
LILIANA I. PICONE, GABRIELA QUAGLIA, FERNANDO O. GARCIA, AND PEDRO LATERRA
}

Authors are Assistant Professor; Graduate Student, Facultad de Ciencias Agrarias (UNMdP)-Estación Experimental Agropecuaria Balcarce (INTA), C.C. 276, (7620) Balcarce, Argentina; director Latin American-Southern Cone, INPOFOS. CONO SUR. (1641) Acassuso, Buenos Aires, Argentina.; and Associate Professor, Facultad de Ciencias Agrarias (UNMdP)-Estación Experimental Agropecuaria Balcarce (INTA), C.C. 276, (7620) Balcarce, Argentina. *Corresponding author (E-mail):lpicone@balcarce.inta.gov.ar

\begin{abstract}
Changes in soil nutrient pools and microbial activity due to fire are important for understanding the availability of nutrients to plants. The objective of this study was to evaluate the effect of fire: 1) on size and seasonal dynamics of labile pools of $\mathbf{C}$ and $\mathrm{N}$ in a short-term after burning; and II) on chemical properties and microbial diversity immediately after fire, in a grassland with Paspalum quadrifarium Lam. Microbial biomass $\mathrm{C}$ and $\mathrm{N}$ tended to be higher in the burned (433 mg C kg-1 and $37 \mathrm{mg} \mathrm{N} \mathrm{kg}^{-1}$ ) than in the unburned treatment (386 mg C kg-1 and $\left.26 \mathrm{mg} \mathrm{N} \mathrm{kg}^{-1}\right)$. Both microbial biomass, decreased at the beginning of the growing season and then recovered at the end of the season. Levels of mineralizable $\mathbf{C}$ and $\mathbf{N}$ were similar in both treatments; however they showed different patterns of seasonal transformations. At initiation of plant growth, concentration of mineralizable $\mathbf{C}$ decreased while amount of mineralizable $N$ increased; but the opposite occurred at the end of the growing season. Increases in microbial biomass coincided with low levels of mineralizable $\mathbf{N}$ and high concentrations of mineralizable $\mathrm{C}$, suggesting a higher immobilization at the end of the season. Immediately after burning, organic $\mathrm{C}$ and $\mathrm{N}$ decreased by 11 and $7 \%$, respectively. Mineral $N$ was almost double, available $P$ increased by $10 \mathrm{mg} \mathrm{kg}^{-1}$; but exchangeable bases, bacterial and actinomycetes population, and urease activity were not affected by burning. Fire can induce immediate changes to the soil; however, long-term studies will be required to evaluate the duration of the effect of fire on soil biological processes and nutrient transformations.
\end{abstract}

Key Words: Paspalum quadrifarium, fire, microbial biomass, soil nutrients, flooding pampa

Flooding Pampa is a region characterized by poorly drained soils that occupies approximately $58,000 \mathrm{~km}^{2}$ in the central-eastern area of Buenos Aires province $\left(35^{\circ} 30^{\prime} \mathrm{N}, 37^{\circ} 40^{\prime} \mathrm{S}, 56^{\circ} 50^{\prime} \mathrm{E}\right.$, $60^{\circ} 30^{\prime} \mathrm{W}$ ) in Argentina. Most of this area is under natural grasslands, which have undergone significant changes in physiognomy and species composition. However, extended stands of pristine plant communities dominated by Paspalum quadrifarium Lam. still exist.

Paspalum quadrifarium Lam. is a warm-season and perennial grass with tall canopy that excludes other species, and forms

Research was funded by Facultad de Ciencias Agrarias-Universidad Nacional de Mar del Plata (UNMdP) Grant AGR 20-93.

Manuscript accepted 16 Jul. 02
Resumen

Estudiar los cambios en los nutrientes del suelo y la actividad microbiana producidos por el fuego es importante para poder entender la disponibilidad de nutrientes para las plantas. EI objetivo de este estudio fue evaluar el efecto del fuego I) sobre el tamaño y la dinámica de los pooles lábiles de $\mathrm{C}$ y $\mathbf{N}$, a corto plazo después de la quema; y II) sobre las propiedades químicas y la diversidad biológica, inmediatamente luego de efectuada la quema, en una pastura natural con predominio de Paspalum quadrifarium Lam. El C y $\mathbf{N}$ de la biomasa microbiana tendieron a ser mayores en el tratamiento de quema $\left(433 \mathrm{mg} \mathrm{C} \mathrm{kg}^{-1}\right.$ y 37 mg $\mathrm{N} \mathrm{kg}^{-1}$ ) que en el tratamiento de no quema $\left(386 \mathrm{mg} \mathrm{C}^{-1} \mathrm{~g}^{-1}\right.$

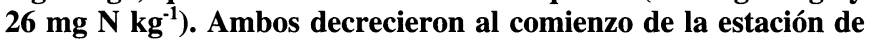
crecimiento de la pastura y se recuperaron al final de la misma. Los niveles de $\mathbf{C}$ y $\mathbf{N}$ mineralizable fueron similares en ambos tratamientos; sin embargo ellos mostraron patrones diferentes de variación estacional. Al inicio del crecimiento vegetal, la concentración de $\mathbf{C}$ mineralizable decreció mientras que el contenido de $\mathbf{N}$ mineralizable incrementó; lo opuesto ocurrió al final de la estación de crecimiento. Los incrementos en biomasa microbiana coincidieron con los bajos niveles de $\mathbf{N}$ mineralizable y la alta concentración de $\mathbf{C}$ mineralizable sugiriendo una mayor inmovilización al comienzo de la estación de crecimiento. Inmediatamente luego del fuego, el $\mathbf{C}$ y $\mathbf{N}$ orgánico decreció en un 11 y 7\%, respectivamente. La concentración de $\mathbf{N}$ mineral fue casi el doble, el $P$ disponible incrementó en $10 \mathrm{mg} \mathrm{kg}-1$; sin embargo las bases intercambiables, y la población de bacteria y actinomicetes como la actividad ureasa no fueron afectadas por el fuego. La quema puede inducir cambios inmediatos en el suelo, no obstante estudios a largo plazo son necesarios para evaluar la duración del efecto del fuego sobre los procesos biológicos y las transformaciones de nutrientes.

dense stands locally known as 'pajonales'. A small amount of the dead foliage falls on the soil surface, and it decomposes at slow rates because of its low nutritive value. About $70-80 \%$ of the aboveground dead plant material remains as standing dead biomass, exceeding $20 \mathrm{Mg}$ dry matter ha ${ }^{-1}$ (Cahuépé and Laterra 1998). Winter-spring burning is a common management practice, which increases the productivity of these grasslands (Sakalauskas et al. 2001), cattle stocking rates (Cahuépé 1990) and nutritive quality of forage (Sacido et al. 1995).

Fire changes soil properties as a result of direct exposure to high temperatures and ash deposition. Furthermore, there are indirect and after-fire longer term effects caused by changes in 
microclimate and plant species composition (Raison et al. 1990). These changes depend on, among other factors, duration of fire, maximum burn temperature, soil texture, and water content (Wright and Bailey 1982). Several studies on the effect of fire on soils have shown changes in soil nutrient levels resulting mainly in total $\mathrm{N}$ losses, but short-term increases in available $\mathrm{N}$ and other nutrients (Biederbeck et al. 1980, Kutiel and Naveh 1987, Fenn et al. 1993, Saá et al. 1998). Soil chemical properties such as exchangeable $\mathrm{Ca}^{++}$, $\mathrm{Mg}^{++}$and $\mathrm{K}^{+}$, and $\mathrm{pH}$ also increase after fire (Tomkins et al. 1991). Microbial biomass is considered an agent of transformation of soil organic materials, and a labile reservoir of nutrients such as $\mathrm{N}, \mathrm{P}$, and $\mathrm{S}$ (Jenkinson and Ladd 1981). Ojima (1987) found that microbial biomass $\mathrm{C}$ and $\mathrm{N}$ were reduced by long-term annual burning ( $>40 \mathrm{yr}$ ), but they were not affected by short-term burning (1-2 yr).

Most research on the effects of fire on grasslands has focused on shifts in plant species composition and plant community productivity (Ricci et al. 1996, Laterra 1997, Laterra et al. 1998) providing scarce information about the impact of fire on soil properties, nutrient availability, and microbial activity. The objective of this study was to evaluate the effect of fire 1) on the size and seasonal dynamics of soil microbial biomass $\mathrm{C}$ and $\mathrm{N}$ in a short-term after burning; and II) on some soil chemical properties and microbial diversity, immediately after a single fire. This study along with others which are being carried out would contribute to obtain a better understanding of soil nutrient transformations and microbial activity in a burned system.

\section{Materials and Methods}

\section{Experimental site}

The study was conducted on several plots in a natural grassland located at San Ignacio $\left(37^{\circ} 10^{\prime} 37^{\prime \prime} \mathrm{S}, 58^{\circ} 25^{\prime} 50^{\prime \prime} \mathrm{W}\right)$, about $20 \mathrm{~km}$ south of Ayacucho district, in the southeast of Buenos Aires province (Argentina). The soil belongs to subgroup Typic Natraquoll, which is generally water-logged during late winter and early spring. The local climate is characterized by a mean annual temperature and median annual precipitation of $15^{\circ} \mathrm{C}$ and 1,029 $\mathrm{mm}$ respectively, with summer droughts and spring floods. The area is a natural grassland composed of 2 types of vegetation, which can be clearly distinguished by their composition and structure. The vegetation that covers most of the area and extends over lower topographical positions is composed of short grasses such as Leersia hexandra Sw., Hordeum pusillum Nutt., and Distichlis spicata (L.) Green. Paspalum quadrifarium Lam. represents patches within the landscape, which are located on slight slopes. The experimental site was selected to take into account the equal physiognomy of patches and the predominance of Paspalum quadrifarium Lam. in the grassland.

\section{Experiment I}

Experiment I was carried out in an area, which had been burned in August 1990. In December 1990, when there was approximately $30 \mathrm{~cm}$ of post-fire regrowth, the eastern area (block I) was grazed for 5 months until May 1991, while the western area (block II) was left ungrazed. From May 1991 to August 1992 both blocks remained ungrazed, and at this time we delimited 4 plots within each block. Treatments, burned and unburned, were randomly assigned to experimental units within a block, with each treatment appearing twice in every block.

Plots were burned on 26 August 1992, in winter. Burning was done up wind to allow a slow and complete fuel combustion, and also a better control of fire. Prior to burning, canopy of Paspalum quadrifarium Lam. had a mean height of $95 \mathrm{~cm}$, and the aerial biomass was 1,555 and $1,808 \mathrm{~g} \mathrm{~m}^{-2}$ in block I and II, respectively. During burning, the mean wind speed was $1.8 \mathrm{~m} \mathrm{sec}^{-1}$ and the maximum temperature at the ground level exceeded $390^{\circ} \mathrm{C}$. Maximum fire temperature was estimated using 8 sets of glass capillary tubes filled with substances, which melted at a different temperature $\left(39-350^{\circ} \mathrm{C}\right)$.

Soil samples were taken from the upper $12 \mathrm{~cm}$ layer of each treatment at different dates: 1, 58, 215, and 360 days after burning. Each soil sample was a composite of 25-30 cores ( $2.5 \mathrm{~cm}$ diam.) collected randomly from each experimental unit, among plants.

\section{Experiment II}

Three homogeneous plots were selected from a site located close to experiment I. These plots were not previously burned. Two treatments, burned and unburned, were set-up in a randomized complete block design with 3 replications. Burning was done on 18 November 1994, in spring. Prior burning, aerial biomass was $1,847 \mathrm{~g} \mathrm{~m}^{-2}$, with $86 \%$ of dead standing biomass. During burning, the mean wind speed was $5 \mathrm{~m} \mathrm{sec}^{-1}$ and the maximum burn temperature at ground level ranged from 152 to $677^{\circ} \mathrm{C}$. Temperature was measured using heat sensitive crayons (Tempilsticks (R), Big Three Industries, Inc. Hamilton Blvd., South Plainfield, N.J. 07080, USA) placed at soil level, among plants.

Soil samples were taken from the 0 - to 5 $\mathrm{cm}$ depth, 1 day after burning in both treatments. Each soil sample was a composite of $25-30$ cores $(2.5 \mathrm{~cm}$ diam.) collected at random from the experimental unit, without removing either the existing litter prior to burning or the ashes after burning.

\section{Biological and chemical analyses}

For chemical analyses (organic C, organic and inorganic $\mathrm{N}, \mathrm{pH}$, available $\mathrm{P}$, cation exchange capacity (CEC), and exchangeable $\mathrm{Ca}^{++}, \mathrm{Mg}^{++}, \mathrm{K}^{+}$, and $\mathrm{Na}^{+}$) soil samples were air-dried and sieved through 2 or $0.5 \mathrm{~mm}$ screens depending on the analytical technique. For microbial and biochemical analyses (microbial biomass $\mathrm{C}$ and $\mathrm{N}$, number of bacteria and actinomycetes, and urease activity) moist soil samples were passed through a $4 \mathrm{~mm}$ mesh to remove plant material.

Soil organic $\mathrm{C}$ content was analyzed with the technique of Walkley and Black (1934), soil organic $\mathrm{N}$ by Kjeldahl digestion (Bremner and Mulvaney 1982), and available $\mathrm{P}$ according to method of Bray and Kurtz (1945). Inorganic $\mathrm{N}\left(\mathrm{NH}_{4}^{+}-\mathrm{N}\right.$ and $\mathrm{NO}_{3}{ }^{-}-\mathrm{N}$ ) was determined on $0.5 \mathrm{M}$ $\mathrm{K}_{2} \mathrm{SO}_{4}$ soil extracts using steam distillation (Bremner and Keeney 1966). Soil pH was measured with a glass-calomel electrode using a soil:water ratio of $1: 2.5$ (weight:volume). Quantification of CEC and exchangeable cations used the procedure of Chapman (1965): $\mathrm{Ca}^{++}$and $\mathrm{Mg}^{++}$ were measured with an atomic absorption spectrophotometer; $\mathrm{K}^{+}$and $\mathrm{Na}^{+}$were measured with a flame photometer.

Soil microbial biomass $\mathrm{C}$ and $\mathrm{N}$ were determined by the chloroform fumigationincubation method (Jenkinson and Powlson 1976). Soil (50 g) was added in each of two, 125-ml Erlenmeyer flasks. Water was added to bring soils to field capacity, and samples were preincubated for 5 days at $25^{\circ} \mathrm{C}$ to stabilize microbial activity. At the end of the preincubation period, 1 of the samples was fumigated with chloroform and the another was left unfumigated. After 24 hours, chloroform was evacuated from the soil samples, and fumigated and unfumigated samples were placed into 1,250-ml glass jars containing a beaker with $15 \mathrm{ml}$ of $0.4 \mathrm{~N} \mathrm{NaOH}$. Jars were closed tightly and incubated for 10 days at $25^{\circ} \mathrm{C}$. Concentration of $\mathrm{CO}_{2}-\mathrm{C}$ 
absorbed by the alkali was determined by titration of excess $0.4 \mathrm{~N} \mathrm{NaOH}$ with $0.1 \mathrm{~N}$ $\mathrm{H}_{2} \mathrm{SO}_{4}$, in presence of $\mathrm{BaCl}_{2}$ (Anderson 1982). Subsequently, mineral $\mathrm{N}\left(\mathrm{NH}_{4}{ }^{+}-\mathrm{N}\right.$ and $\mathrm{NO}_{3}^{-}-\mathrm{N}$ ) in the samples was extracted with $0.5 \mathrm{M} \mathrm{K}_{2} \mathrm{SO}_{4}$ and extracts were analyzed by steam distillation (Bremner and Keeney 1966).

We express microbial biomass $\mathrm{C}$ and $\mathrm{N}$ as the difference in $\mathrm{CO}_{2}-\mathrm{C}$ evolved and $\mathrm{N}$ mineralized between fumigated and unfumigated samples, to avoid the confusion of using different conversion factors $\left(\mathrm{K}_{\mathrm{C}}\right.$ and $\mathrm{K}_{\mathrm{N}}$ ). When comparing with other data, the microbial biomass $\mathrm{C}$ and $\mathrm{N}$ were calculated according to the equation suggested by Voroney and Paul (1984):

Microbial biomass $\mathrm{C}\left(\mathrm{mg} \mathrm{C} \mathrm{kg}^{-1}\right)=$

$\mathrm{Cf}-\mathrm{Cu} / \mathrm{kc}$

where:

$\mathrm{Cf}=\mathrm{CO}_{2}-\mathrm{C}$ evolved from fumigated sample

$\mathrm{Cu}=\mathrm{CO}_{2}-\mathrm{C}$ evolved from unfumigated sample

$\mathrm{K}_{\mathrm{c}}=0.41$ (fraction of microbial biomass converted to $\mathrm{CO}_{2}$ )

Microbial biomass $\mathrm{N}\left(\mathrm{mg} \mathrm{N} \mathrm{kg}^{-1}\right)=$

$\mathrm{Nf}-\mathrm{Nu} / \mathrm{K}_{\mathrm{N}}$

where:

$\mathrm{Nf}=\mathrm{NH}_{4}{ }^{+}-\mathrm{N}$ and $\mathrm{NO}_{3}{ }^{-}-\mathrm{N}$ mineralized from fumigated sample

$\mathrm{Nu}=\mathrm{NH}_{4}{ }^{+}-\mathrm{N}$ and $\mathrm{NO}_{3}{ }^{-}-\mathrm{N}$ mineralized from unfumigated sample

$\mathrm{KN}=(-0.014 \times(\mathrm{Cf} / \mathrm{Nf}))+0.39$

$\mathrm{Cf}=\mathrm{CO}_{2}-\mathrm{C}$ evolved from fumigated sample Indices of mineralizable $\mathrm{C}$ and $\mathrm{N}$ were obtained from unfumigated samples for microbial biomass. They were calculated as the difference of $\mathrm{CO}_{2}-\mathrm{C}$ or inorganic $\mathrm{N}$ concentration before and after incubation, and were expressed as $\mathrm{mg} \mathrm{CO}_{2}-\mathrm{C}$ or $\mathrm{mg}$ inorganic $\mathrm{N}$ per $\mathrm{kg}$ of soil.

Microbial populations were quantified using a dilution pour- plate technique. Bacteria were determined on nutrient agar supplemented with $5 \mathrm{~g} \mathrm{liter}^{-1}$ of glucose (Zuberer 1994), and actinomycetes on casein-starch medium (Kuster and Williams 1964). Petri plates were incubated at $25^{\circ} \mathrm{C}$ for 5 days for bacteria count, and 10 days for actinomycetes count. Total number of bacteria and actinomycetes were expressed as log value of colony forming unit per $\mathrm{g}$ of soil $\left(\mathrm{cfu} \mathrm{g}^{-1}\right)$. Urease activity was measured according to no-buffer method of Douglas and Bremner (1970) and reported as mg N per $\mathrm{kg}$ of soil per hour.

Results are expressed on the basis of dry soil weight. Soil water content was determined gravimetrically by oven drying at $105^{\circ} \mathrm{C}$ for 48 hours.
Table 1. Summary of analysis of variance for microbial biomass carbon (MBC) and nitrogen $(\mathrm{MBN})$, and mineralizable carbon (MC) and nitrogen (MN) at 0-12 cm depth in a grassland soil.

\begin{tabular}{lccccc}
\hline \hline \multirow{2}{*}{ Source of variation } & $\mathrm{df}$ & $\mathrm{MBC}$ & $\mathrm{MBN}$ & $\mathrm{MC}$ & $\mathrm{MN}$ \\
\hline Burning & 1 & $17.11 \mathrm{~ns}$ & $5.99 \mathrm{~ns}$ & $0.02 \mathrm{~ns}$ & $0.25 \mathrm{~ns}$ \\
Block & 1 & $13.26 \mathrm{~ns}$ & $1.79 \mathrm{~ns}$ & $0.37 \mathrm{~ns}$ & $0.36 \mathrm{~ns}$ \\
Date & 3 & $2.64^{*}$ & $1.74 \mathrm{~ns}$ & $16.76^{* * *}$ & $2.32 \mathrm{~ns}$ \\
Burning x block & 1 & $0.03 \mathrm{~ns}$ & $1.21 \mathrm{~ns}$ & $4.16^{*}$ & $2.67 \mathrm{~ns}$ \\
Burning x date & 3 & $0.62 \mathrm{~ns}$ & $0.97 \mathrm{~ns}$ & $1.77 \mathrm{~ns}$ & $0.31 \mathrm{~ns}$ \\
\hline
\end{tabular}

*,*** significant at $\mathrm{P}<0.10$, and $\mathrm{P}<0.0001$, respectively. $\mathrm{ns}=$ not significant.

\section{Statistical analyses}

Data were analyzed using the GLM procedure of SAS (SAS Institute Inc. 1996). In experiment $\mathrm{I}$, content of microbial biomass $\mathrm{C}$ and $\mathrm{N}$, and mineralizable $\mathrm{C}$ and $\mathrm{N}$ on different dates were subjected to an analysis of variance as a split-plot arrangement in a randomized complete block design, with 2 replications. The main plot was the treatment (unburned and burned), and subplot was the sampling date. In experiment II, variables were analyzed according to a randomized complete block design, with 3 replications. Means separation, where necessary, was made by using the least significance difference test (LSD) with 5 or $10 \%$ probability.

\section{Results and Discussion}

\section{Experiment I}

Fire and grazing can influence $\mathrm{N}$ cycling in grassland ecosystems by affecting the spatial distribution of accumulated plant biomass, and $\mathrm{N}$ additions and losses (Hobbs et al. 1991). In this study, there was no effect due to previous grazing on the size of microbial biomass $\mathrm{C}$ and $\mathrm{N}$ (Table 1). The reason is probably because the area was grazed for a relatively short time at a low stocking rate, and both blocks remained closed for 15 months before estimations of microbial biomass. Averaged across all treatments and sampling dates, microbial biomass $\mathrm{C}$ was 421 $\mathrm{mg} \mathrm{CO}_{2}-\mathrm{C} \mathrm{kg}^{-1}$, which is equivalent to $1,027 \mathrm{mg} \mathrm{CO}-\mathrm{C} \mathrm{kg}^{-1}$ according to equation (1). This value is higher than those observed for other grasslands (Fenn et al. 1993, Garcia and Rice 1994). Although microbial $\mathrm{C}$ is a small fraction of the total soil organic $\mathrm{C}$, about $1 \%$ of $67.8 \mathrm{~g} \mathrm{C} \mathrm{kg}^{-1}$, it has a rapid rate of turnover (Jenkinson and Ladd 1981), and represents a substantial pool of soil nutrients. Microbial biomass $\mathrm{C}$ was not affected by burning (Table 1), but tended to be higher in the burned (433 $\mathrm{mg} \mathrm{CO}_{2}-\mathrm{C} \mathrm{kg}^{-1}$ ) than in the unburned treatment $\left(386 \mathrm{mg} \mathrm{CO}-\mathrm{C} \mathrm{kg}^{-1}\right)$ (Fig. 1a) as has been observed in annually- burned tallgrass prairie (García and Rice 1994). Soil microbial biomass $C$ in the top $12 \mathrm{~cm}$ of soil ranged from 277 to $581 \mathrm{mg}$ $\mathrm{CO}_{2}-\mathrm{C} \mathrm{kg}^{-1}$ in the burned treatment and from 170 to $569 \mathrm{mg} \mathrm{CO} 2-\mathrm{C} \mathrm{kg}^{-1}$ in the unburned treatment. This response was a result of the higher temperatures reached by the soil during burning (García 1992), which increased plant residue decomposition rates and the mineralization rates of organic matter (Risser and Parton 1982). Microbial biomass $C$ varied marginally due to sampling date (Table 1), but seasonal dynamics was not significantly affected by burning. The general pattern for microbial biomass $\mathrm{C}$ was to have a decrease at the beginning of plant growth (in early spring, October), a recovery by the end of the growing season (in late summer, March), and was low in winter (August) (Fig. 2a). It was likely that the significant drop in microbial biomass $\mathrm{C}$ in October was due to the reduced availability of organic compounds to soil microorganisms. At the March sampling, microbial biomass $\mathrm{C}$ was significantly higher than it was observed the previous month. As the growing season progressed, the
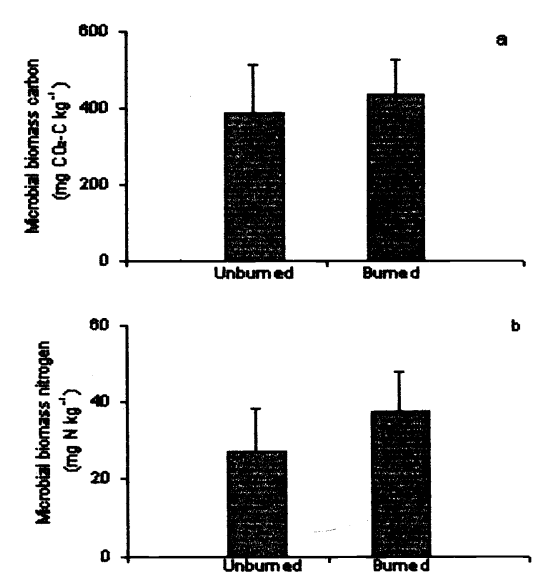

Fig. 1. Content of soil microbial biomass carbon (a) and nitrogen (b) at 0-12 cm depth in unburned and burned grassland soil. Vertical bars represent standard deviations $(n=16)$. 

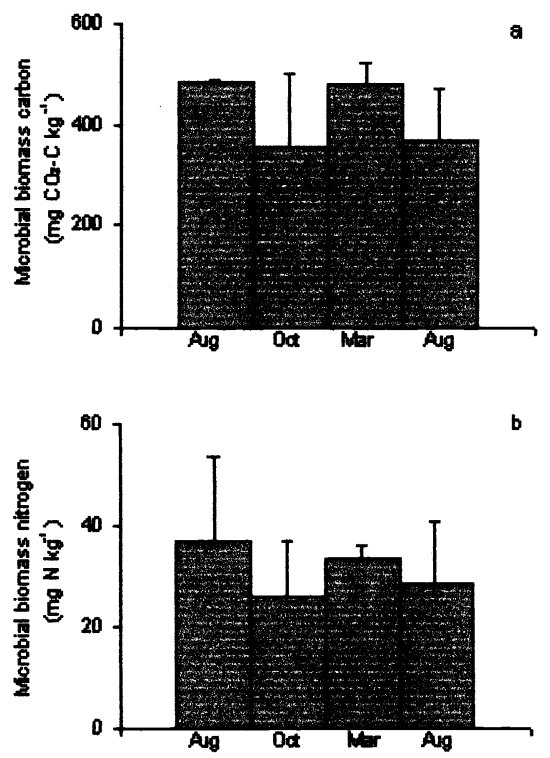

Fig. 2. Seasonal dynamics of soil microbial biomass carbon (a) and nitrogen (b) in a grassland soil at 0-12 cm depth. Vertical bars indicate standard deviations $(n=8)$.

warmer temperatures along with the occurrence of precipitation $(378 \mathrm{~mm}$ from September to March) (Fig. 3) increased root activity and root exudates, which result in increased microbial biomass $\mathrm{C}$ at the end of summer or beginning of fall. Roots are an important source of easily decomposable $\mathrm{C}$ for microbial activity in the perennial grassland, where the majority of plant $\mathrm{C}$ is located belowground (Coleman 1976, Coleman et al. 1983). Lynch and Panting (1980) found that soil microbial biomass increased with root growth and rooting density. Moisture and temperature may also affect the microbial biomass by affecting plant growth and the amount of available substrate for microor- ganisms (García and Rice 1994). Microbial biomass $\mathrm{C}$ was low in soil samples collected in August of the second growing season, when temperature and soil moisture were unfavorable to microbial growth. During winter, temperatures were colder and there were 60 days of drought immediately before sampling (Fig. 3).

Soil microbial biomass $\mathrm{N}$ was $31 \mathrm{mg} \mathrm{N}$ $\mathrm{kg}^{-1}$ for the 0 - to $12-\mathrm{cm}$ depth averaged across all treatments and sampling dates. This value is equivalent to $110 \mathrm{mg} \mathrm{N} \mathrm{kg}^{-1}$ according to equation (2), which is similar or higher than those reported for other grasslands (Fenn et al. 1993, Garcia and Rice 1994). The average C:N ratio of microbial biomass $(9: 1)$ was typical of microbial biomass $\mathrm{C}: \mathrm{N}$ ratios (Paul and Voroney 1980). Soil microbial biomass N was not significantly affected either by burning or sampling date (Table 1). However, it tended to be higher in the burned (37 $\left.\mathrm{mg} \mathrm{N} \mathrm{kg}^{-1}\right)$ than in the unburned treatment $\left(26 \mathrm{mg} \mathrm{N} \mathrm{kg}^{-1}\right)$ (Fig. $1 \mathrm{~b})$, and showed a pattern of seasonal variation similar to that of microbial biomass $\mathrm{C}$ (Fig. 2b). The decline in biomass $\mathrm{N}$ between August and October, assumed to be a result of mineralization, amount to 13 $\mathrm{kg} \mathrm{N} \mathrm{ha}{ }^{-1}$ in the top $12 \mathrm{~cm}$ of soil, therefore a substantial quantity of $\mathrm{N}$ will be available at the beginning of the active plant growth. Clark (1977) indicated that belowground $\mathrm{N}$ translocation may account for $33 \%$ of the aboveground $\mathrm{N}$ requirements in shortgrass prairie, with the remainder provided by mineralization of soil organic $\mathrm{N}$.

Mineralizable $\mathrm{N}$ has been suggested as an index of the soil capacity to supply mineralized $\mathrm{N}$, while mineralizable $\mathrm{C}$ is an index of microbial activity. These pools include the biomass pool and other nonbiomass active fractions of the soil organic matter. It is important to note that these

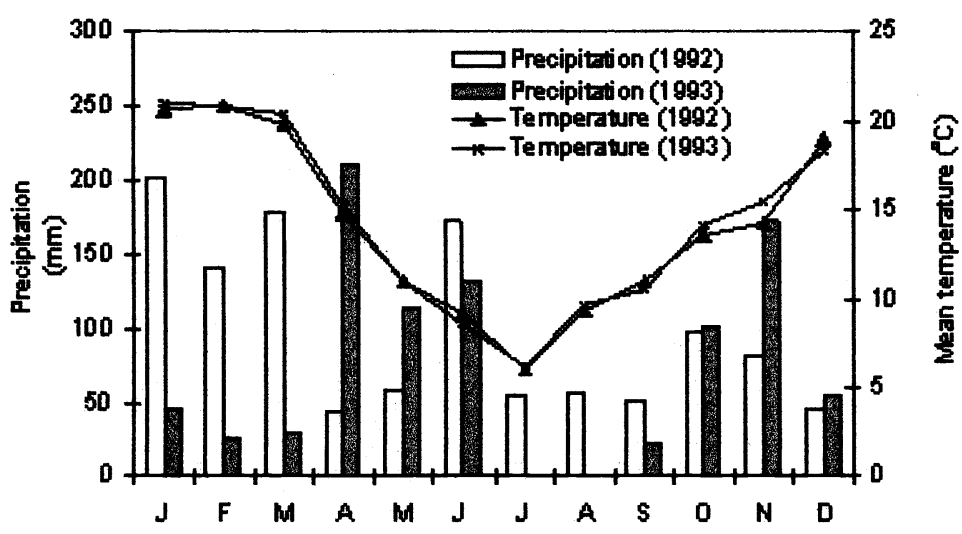

Fig. 3. Weather conditions during the studied period. measurements obtained using the shortterm incubation may not reflect the entire mineralizable organic pools (Cabrera and Kissel 1988).

The size of these pools was not affected by burning, and only mineralizable $\mathrm{C}$ significantly varied with sampling dates (Table 1). Mineralizable $\mathrm{C}$ and $\mathrm{N}$, averaged burned and unburned treatment, was $217 \mathrm{mg} \mathrm{CO}_{2}-\mathrm{C} \mathrm{kg}^{-1}$ and $27 \mathrm{mg} \mathrm{N} \mathrm{kg}^{-1}$ for the 0 - to $12-\mathrm{cm}$ depth, respectively (Fig. $4 \mathrm{a}$ and $4 \mathrm{~b}$ ). In the early spring (October),
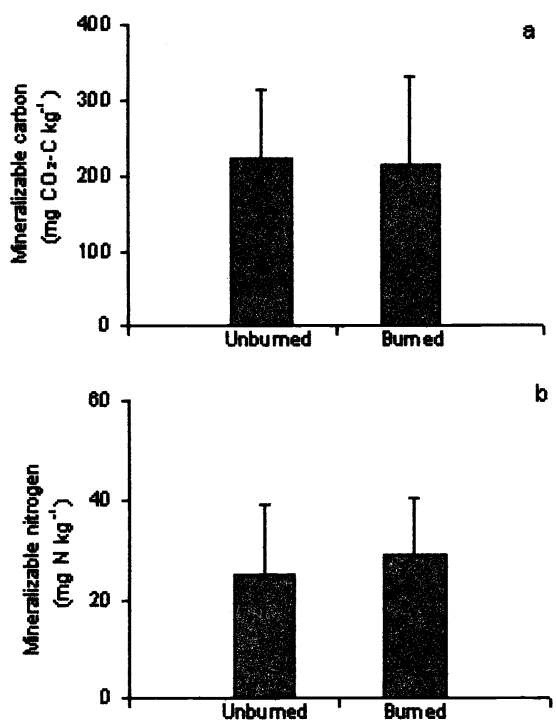

Fig. 4. Mineralizable carbon (a) and nitrogen (b) at 0-12 cm depth in unburned and burned grassland soil. Vertical bars represent standard deviations $(n=16)$.

the grassland soil tended to have a lower production of mineralizable $\mathrm{C}$ but higher inorganic $\mathrm{N}$ content suggesting a lower immobilization of $\mathrm{N}$ into microbial biomass (Fig. 5a and 5b). In fact, microbial biomass showed an important drop at that time. At the end of the growing season (March) occurred the opposite, the grassland soil had higher microbial activity with lower inorganic $\mathrm{N}$ content indicating a higher immobilization, which resulted in more microbial growth and then in microbial biomass (Fig 5a and 5b). Also, at this time the plant uptake of nutrients decreased and $\mathrm{N}$ mineralized is either immobilized by microorganisms or accumulated as inorganic $\mathrm{N}$. Ratio of $\mathrm{CO}_{2}$ evolved : $\mathrm{N}$ mineralized has been suggested as an index of $\mathrm{N}$ immobilization (Schimel 1986). If this ratio is high it means that soil has the ability to immobilize $\mathrm{N}$, but if the ratio is low, the $\mathrm{N}$ mineralization may be high. The calculated ratio 

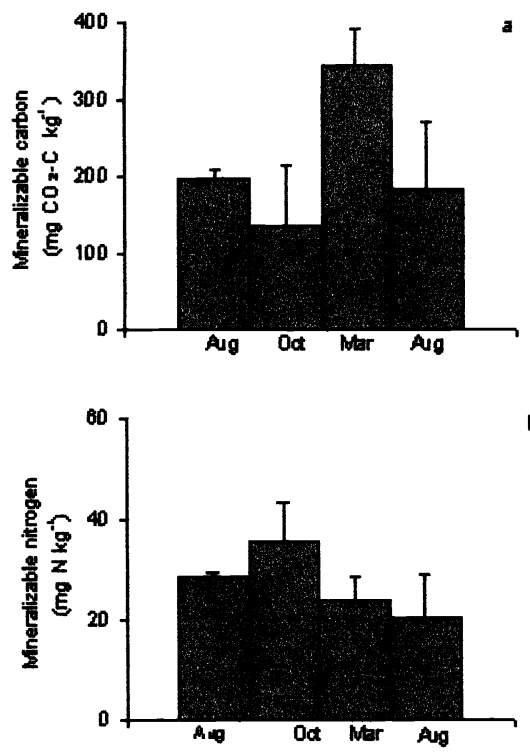

Fig. 5. Temporal dynamics of mineralizable carbon (a) and nitrogen (b) in a grassland soil at 0-12 cm depth. Vertical bars represent standard deviations $(n=8)$.

(data not shown) corroborated the previous observations, and it showed between 3-4 times more microbial activity per unit of mineralizable $\mathrm{N}$ at the initiation of plant growth and 14 more microbial activity per unit of mineralizable $\mathrm{N}$ at the end of the growing season, suggesting higher immobilization at the latter date. The amount and quality of organic substrates available to microorganisms are important controls over the microbial immobilization-mineralization process (Schimel 1986), and may partially explain the changes observed in immobilization-mineralization balance. When the substrate available to microorganisms was the plant tissue with low $\mathrm{C}: \mathrm{N}$ ratio as a grassland regrowth, which was enhanced by moist conditions in early spring, $\mathrm{N}$ immobilization was likely reduced. However, as the easily degradable $\mathrm{C}$ compounds disappeared throughout the growing season, microbial growth and $\mathrm{N}$ immobilization were likely increased. At the sampling of August in the second growing season, microbial activity and biomass were affected not only by the quality of substrate because most of the plant material was senescent, but also by environmental conditions, there was a previous drought, which decreased the pools of $\mathrm{N}$ and $\mathrm{C}$.

In conclusion, in the short term, burning had no significant effect on the size of microbial biomass $\mathrm{C}$ and $\mathrm{N}$ or mineralizable $\mathrm{C}$ and $\mathrm{N}$ in the surface soil of grassland, but microbial biomass tended to be higher in the burned soil. Soil microbial biomass was seasonally dependent, affecting the process of mineralization and immobilization of N. Seasonal changes in microbial biomass, which were not modified by burning, could be related to fluctuations in organic inputs during the growing season, and soil moisture and temperature. The increase in mineralizable $\mathrm{N}$ at the beginning of the growing season matched with less mineralizable $\mathrm{CO}_{2}-\mathrm{C}$ and microbial biomass; whereas the decrease in mineralizable $\mathrm{N}$ coincided with high mineralizable $\mathrm{CO}_{2}-\mathrm{C}$ and microbial biomass at the end of the growing season.

\section{Experiment II}

After field burning it is not possible to separate the effects of heat and ash on several processes in the soil, thus in this experiment we evaluate the potential effect of heat and ash deposition on microbial diversity and some chemical properties, immediately after a single burning.

The immediate effect of fire was to decrease the soil organic $\mathrm{C}$ content in the 0 - to $5 \mathrm{~cm}$ depth. Organic carbon from plant debris, roots, microbial biomass, and organic matter combusted due to the high temperature reached by the soil under fire. The decrease was $11 \%$ (Table 2), however it is likely that $\mathrm{C}$ losses only by heating were even higher in the surface layer because ashes can supply organic matter contributing to mask the differences in organic $\mathrm{C}$ content between burned and unburned treatments. As in the case of soil organic $\mathrm{C}$, organic $\mathrm{N}$ content significantly decreased in the burned soil (Table 2). The the level of total $\mathrm{N}$, when soil and layers of organic residues remain wet less than $25 \%$ of total soil $\mathrm{N}$ is lost (DeBano et al. 1979). In this study, high soil water content (Table 2) could account for the low percentage of $\mathrm{N}$ losses. The $\mathrm{C}: \mathrm{N}$ ratio in the surface of the burned soil $(14: 1)$ was similar to that in the unburned one $(13: 1)$ because the decrease in organic $\mathrm{N}$ was proportional to the loss in organic $\mathrm{C}$. This agrees with that reported by Raison et al. (1985), in that $\mathrm{N}$ compounds are usually lost in direct proportion to the amount of oxidized C.

In spite of the reduction in soil organic $\mathrm{N}$ due to burning, the levels of inorganic $\mathrm{N}$ $\left(\mathrm{NH}_{4}{ }^{+}\right.$and $\left.\mathrm{NO}_{3}\right)$ for plants were almost double in the burned soil (Table 2). The immediate increase in inorganic $\mathrm{N}$ was probably a consequence of physicochemical breakdown of soil organic matter by heat (Biederbeck et al. 1980, Kovacic et al. 1986), since the release of inorganic $N$ through nitrification process requires a period of time elapsed after burning. Ashes can add mineral N, but in small amounts (Raison 1979). The elevated concentration of inorganic $\mathrm{N}$, in unburned soil, indicates that this ecosystems has a considerable potential of $\mathrm{N}$ mineralization.

The level of available $P$ significantly increased from 21.5 to $31.7 \mathrm{mg} \mathrm{kg}^{-1}$, after burning (Table 2). This increase in $\mathrm{P}$ could arise from the release of $\mathrm{P}$ as $\mathrm{H}_{2} \mathrm{PO}_{4}$ - by heating (Fassbender 1975), which formed phosphates of $\mathrm{Ca}, \mathrm{Fe}$, and $\mathrm{Al}$ that are extractable with the technique used for $\mathrm{P}$ determination. Phosphorous may be also added to the soil surface in ashes, mainly

Table 2. Changes in soil nutrient pools and chemical properties at the $0-5 \mathrm{~cm}$ depth in the unburned and burned grassland soil.

\begin{tabular}{|c|c|c|c|}
\hline \multirow[b]{2}{*}{ Soil characteristics } & \multicolumn{2}{|c|}{ Treatment } & \multirow[b]{2}{*}{ Significance } \\
\hline & Unburned & $\overline{\text { Burned }}$ & \\
\hline Water content $\left(\mathrm{g} \mathrm{g}^{-1}\right)$ & 0.48 & 0.46 & ns \\
\hline Organic $\mathrm{C}\left(\mathrm{g} \mathrm{kg}^{-1}\right)$ & 60.65 & 54.10 & ** \\
\hline Organic $\mathrm{N}\left(\mathrm{g} \mathrm{kg}^{-1}\right)$ & 4.37 & 4.07 & $* *$ \\
\hline $\mathrm{NH}_{4}{ }^{+}-\mathrm{N}$ plus $\mathrm{NO}_{3}^{-}-\mathrm{N}\left(\mathrm{mg} \mathrm{kg}^{-1}\right)$ & 39.72 & 69.72 & ** \\
\hline Available $\mathrm{P}\left(\mathrm{mg} \mathrm{kg}^{-1}\right)$ & 21.50 & 31.77 & * \\
\hline $\mathrm{CEC}\left(\mathrm{cmol}_{\mathrm{C}} \mathrm{kg}^{-1}\right)$ & 26.70 & 25.92 & ns \\
\hline $\mathrm{Ca}^{++}\left(\mathrm{cmol}_{\mathrm{c}} \mathrm{kg}^{-1}\right)$ & 12.65 & 12.72 & ns \\
\hline $\mathrm{Mg}^{++}\left(\mathrm{cmol}_{\mathrm{c}} \mathrm{kg}^{-1}\right)$ & 5.28 & 5.53 & ns \\
\hline $\mathrm{K}^{+}\left(\mathrm{cmol}_{\mathrm{c}} \mathrm{kg}^{-1}\right)$ & 1.96 & 2.03 & ns \\
\hline $\mathrm{Na}^{+}\left(\mathrm{cmol}_{\mathrm{c}} \mathrm{kg}^{-1}\right)$ & 0.56 & 1.35 & ns \\
\hline $\mathrm{pH}$ water & 6.85 & 7.23 & $* *$ \\
\hline
\end{tabular}

$*, * *$ significant at $\mathrm{P}<0.1$ and $\mathrm{P}<0.05$, respectively. ns $=$ not significant

organic $\mathrm{N}$ loss, $7 \%$, was probably a result of volatilization of $\mathrm{N}$ compounds during fire (DeBano et al. 1979). Soil moisture content at the time of fire strongly affects

as polyphosphates of $\mathrm{Ca}$ (Raison 1979). The high levels of inorganic $\mathrm{N}$ and available $\mathrm{P}$ may affect the growth of the plant 
Table 3. Enumeration of bacterial and actimomycetes population, and urease activity at the 0-5 cm depth in the unburned and burned grassland soil.

\begin{tabular}{lccc}
\hline \hline & \multicolumn{2}{c}{ Treatment } & \\
\cline { 2 - 4 } Soil characteristics & Unburned & Burned & Significance \\
\hline Bacteria $\left(\log \mathrm{cfu} \mathrm{g}{ }^{-1}\right)$ & 7.31 & 6.93 & $\mathrm{~ns}$ \\
Actinomycetes $\left.(\operatorname{log~cfu~g})^{-1}\right)$ & 5.45 & 5.23 & $\mathrm{~ns}$ \\
Urease activity $\left(\mathrm{mg} \mathrm{N} \mathrm{kg}^{-1} \mathrm{~h}^{-1}\right)$ & 139.9 & 131.2 & $\mathrm{~ns}$ \\
\hline
\end{tabular}

ns = not significant.

community in the first growing season after fire. In fact, aboveground plant production increased following the winter burning of the grassland (Sakalauskas et al. 2001).

The decrease in organic matter content was not reflected in a decrease of CEC, the values of CEC were similar before and after burning (Table 2). Exchangeable $\mathrm{Ca}^{++}, \mathrm{Mg}^{++}, \mathrm{K}^{+}$, and $\mathrm{Na}^{+}$were not affected by burning either (Table 2). In horizons rich in organic matter and with buffer capacity, changes in even the most usually affected properties such as exchangeable cations may not be detectable against natural variation of soil (Raison et at. 1990).

It was observed an immediate and significant increase in $\mathrm{pH}$ after single burning (Table 2). The increase in $\mathrm{pH}$ of 0.38 units compared to unburned soil may be the result of addition of carbonates and oxides of alkali and alkaline earth metals by ashes (Raison et al. 1990) and/ or organic acid losses during the fire (Ulery et al. 1993). The moderate change in $\mathrm{pH}$ was due to the high buffer capacity of this soil (Fabrizzi et al. 1998) and the short time that had elapsed after burning, which may not allow the soil to reach equilibrium $\mathrm{pH}$.

Although burning had no significant effect on numbers of bacteria and actinomycetes in the top $5 \mathrm{~cm}$ of soil (Table 3), trends indicate that burned soil had lower populations of microorganisms. The difference between unburned and burned soil was up to $0.38 \log$ units in the case of bacteria and $0.22 \mathrm{log}$ units for actinomycetes. It appears that the high soil moisture (Table 2) alleviated the effect of burning, because after burning the soil moisture still remained high.

Urease activity was not effected by burning (Table 3), although fire temperature was high enough to denature the enzyme. Tiwari et al. (1988), working with different types of soil, registered urease activity after the soils were ignited at $450^{\circ} \mathrm{C}$. Inorganic catalytic agents are formed in the ignited soil and these are responsible for the hydrolysis of urea. The degree of urea hydrolysis varied with the quality or quantity of the catalytic agents present (Tiwari et al. 1988).
The results indicate that immediately after burning there were losses in total organic $\mathrm{C}$ and $\mathrm{N}$ in the first $5 \mathrm{~cm}$ of soil, presumably because they had been volatilized by the fire; however, substantial amounts of $\mathrm{C}$ and $\mathrm{N}$ were conserved not affecting the quality of soil. Burning was beneficial for plant nutrition because available $\mathrm{N}$ and $\mathrm{P}$ increased, and exchangeable $\mathrm{Ca}^{++}, \mathrm{Mg}^{++}, \mathrm{K}^{+}$, and $\mathrm{Na}^{+}$ were not affected. However, these increases in available $\mathrm{N}$ and $\mathrm{P}$ may be temporary since $\mathrm{N}$ is susceptible to losses and $\mathrm{P}$ reacts with colloids of soil. Burning had no significant effect on numbers of bacteria and actinomycetes, perhaps because of the high soil water content of the soil. Urease activity remained at similar level after burning. Fire provides an alternative to induce immediate changes on the soil; however, long-term studies will be required to evaluate the duration of the effect of fire on soil biological processes and nutrient transformations, and their effects on the ecosystem productivity.

Anderson, J.P.E. 1982. Soil respiration, p 837-871. In: A.L. Page et al. (ed.). Methods of soil analysis. Part 2. $2^{\text {nd }}$ ed Agron. Monogr. 9. ASA and SSSA, Madison, Wisc.

Biederbeck, V.O., C.A. Campbell, K.E. Bowren, M. Schnitzer, and R.N. McIver. 1980. Effect of burning cereal straw on soil properties and grain yields in Saskatchewan. Soil Sci. Soc. Amer. J. 404:103-111.

Bray, R.H., and L.T. Kurtz. 1945. Determination of total, organic and available forms of phosphorus in soils. Soil Sci. 59: $39-46$.

Bremner, J.M. and D.R. Keeney. 1966. Determination and isotope-ratio analysis of different forms of nitrogen in soils: 3 Exchangeable ammonium, nitrate and nitrite by extraction-distillation methods. Soil Sci. Soc. Amer. Proc. 30:577-582.

Bremner, J.M. and C.S. Mulvaney. 1982. Nitrogen-total, p.595-624. In: A. L. Page et al. (ed) Methods of soil analysis. Part 2 Chemical and microbiological properties. 2 nd ed. Agron. 9. ASA and SSSA. Madison, Wisc.

\section{Literature Cited}

Cabrera, M.L. and D.E. Kissel. 1988. Potentially mineralizable nitrogen in disturbed and undisturbed soil samples. Soil Sci. Soc. Amer. J. 52:1010-1015.

Cahuépé, M. A. 1990. Manejo racional de la paja colorada. Revista CREA. Argentina 143:62-69.

Cahuépé, M. A., and P. Laterra. 1998. Manejo de pajonales de paja colorada basado en estudios ecológicos. Estación Experimental Agropecuaria INTA Balcarce. Bol. Tecn. 145.

Chapman, H.D. 1965. Cation-exchange capacity, p. 891-898. In: C. A. Black et al. (ed.). Methods of soil analysis. Part 2. Chemical and microbiological properties. $2^{\text {nd }}$ ed Agron. 9. ASA and SSSA. Madison, Wisc.

Clark, F.E. 1977. Internal cycling of 15 Nitrogen in shortgrass prairie. Ecol. 58: 1322-1333.

Coleman, D.C. 1976. A review of root production processes and their influence on soil biota in terrestrial ecosystems, p. 417-434. In: M. Anderson and A. Macfayden (ed.) The role of terrestrial and aquatic organisms in decomposition processes. Blackwell Scientific, Oxford, England.

Coleman, D.C., C.P.P. Reid, and C.V. Cole.1983. Biological strategies of nutrient cycling in soil systems. Advances in Ecol. Res.. 13: 1-55.

DeBano, L.F., G.E. Eberlein, and P.H. Dunn. 1979. Effects of burning on chaparral soils :I Soil nitrogen. Soil Sci. Soc. Amer. J. 43: 504-509.

Douglas, L.A. and J.M. Bremner. 1970. Extraction and colorimetric determination of urea in soil. Soil Sci. Soc. Amer. Proc. 34:859-862.

Fabrizzi, K., L.I. Picone, A. Berardo, and F. Garcia. 1998. Efecto de la fertilización nitrogenada y fosfatada en las propiedades químicas de un argiudol típico. Ciencia del Suelo 16:71-76.

Fassbender, H.W. 1975. Experimentos de laboratorio para el estudio del efecto del fuego de la quema de restos vegetales sobre las propiedades del suelo. Turrialba 25:249-254.

Fenn, M.E., M.A. Poth, P.H. Dunn, and S.C. Barro. 1993. Microbial N and biomass respiration and $\mathrm{N}$ mineralization in soils beneath two chaparral species along a fire-induced age gradient. Soil Biol. Biochem. 25:457-466.

García, F.O. 1992. Carbon and nitrogen dynamics and microbial ecology in tallgrass prairie. Ph. D. Thesis, Univ. Kansas State. Manhattan, Kans.

García, F.O. and C.W. Rice. 1994. Microbial biomass dynamics in tallgrass prairie. Soil Sci. Soc. Amer. J. 58:816-823.

Hobbs, N.T., D.S. Schimel, C.E. Owensby, and D.S. Ojima. 1991. Fire and grazing in the tallgrass prairie: contingent effects on nitrogen budgets. Ecol. 72: 1374-1382.

Jenkinson, D.S. and J.N. Ladd. 1981. Microbial biomass in soil: measurement and turnover. p. 415-471. In : E.A. Paul and J.N. Ladd (ed.) Soil Biochemistry. Vol 5. Marcel Dekker, New York. 
Jenkinson, D.S. and D.S. Powlson. 1976. The effects of biocidal treatments on metabolism in soil. V. A method for measuring soil biomass. Soil Biol. Biochem. 8:209-213.

Kovacic, D.A., D.M. Swift, J.E. Ellis, and T.E. Hakonson. 1986. Immediate effects of prescribed burning on mineral soil nitrogen in ponderosa pine of New Mexico. Soil Sci. 141:71-76.

Kuster, E. and S.T. Williams. 1964. Selection of media for isolation of streptomycetes. Nature (London). 202:928-929.

Kutiel, P. and Z. Naveh. 1987. The effect of fire on nutrients in a pine forest soil. Plant Soil 104:269-274.

Laterra, P. 1997. Post-burn recovery in the flooding Pampa: Impact of an invasive legume. J. Range Manage. 50:274-277.

Laterra, P., O.R. Vignolio, L.G. Hidalgo, O.N. Fernández, M.A. Cauhépé, and N. O. Maceira 1998. Dinámica de pajonales de paja colorada (Paspalum spp) manejados con fuego y pastoreo en la Pampa Deprimida Argentina. Ecotrópicos. 11:41-149.

Lynch, J.M. and L.M. Panting. 1980. Cultivation and the soil biomass. Soil Biol.Biochem. 12:29-33.

Ojima, D.S. 1987. The short-term and longterm effects of burning on tallgrass prairie ecosystem properties and dynamics. Ph D. Diss., Colorado State Univ., Fort Collins, Colo. (Diss. Abstr. 87-25646)

Paul, E.A., and R.P. Voroney. 1980. Nutrient and energy flows through soil microbial biomass, p. 215-237. In: D. C. Ellwood et al.(ed.) Contem. Micro. Ecol. Academic Press, London.

Raison, R.J. 1979. Modification of the soil environment by vegetation fires, with particular reference to nitrogen transformations: A review. Plant Soil 51:73-108.
Raison, R.J., P.K. Khanna, and P.V. Woods 1985. Mechanisms of element transfer to the atmosphere during vegetation fire. Can. J. For. Res. 15:132-140.

Raison, R. J., H. Keith, and P.K. Khanna. 1990. Effects of fire on the nutrient supplying-capacity of forest soils, p. 39-54. In: W. J. Dyck and C. A. Mees (ed) Impact of intensive harvesting on forest site productivity. Proceedings, IEA/BE A3 Workshop, South Island, New Zealand, March 1989. IEA/BE T6/A6 Report No 2. Forest Res. Inst., Rotorua, New Zealand, FRI Bull. No. 159.

Ricci, L.J., P. Laterra, O.R. Vignolio, and O.N. Fernández. 1996. Dinámicas del banco de semillas de Paspalum quadrifarium Lam. en la Pampa Deprimida, Argentina. Revista de la Facultad de Agronomía, La Plata. 101:25-33.

Risser, P. and W.J. Parton. 1982. Ecological analysis of a tallgrass prairie: Nitrogen cycle. Ecol. 63:1342-1351.

Saá, A., M.C. Trasar-Cepeda, and $T$. Carballas. 1998. Soil P status and phosphomonoesterase activity of recently burnt and unburnt soil following laboratory incubation. Soil Biol. Biochem. 30:419-428.

Sacido, M., L. Hidalgo, and M. Cauhépé. 1995. Efectos del fuego y la defoliación sobre el valor nutritivo de matas de paja colorada (Paspalum quadrifarium). p. 142-146. In: XIV Reunión Latinoamericana de Producción Animal y XIX Congreso de AAPA, Mar del Plata, Buenos Aires, Argentina.

Sakalauskas, K.M., J.L. Costa, P. Laterra, and L. Aguirrezabal. 2001. Effects of burning on soil water content and water use by Paspalum quadrifarium. Agr. Water Manage. 50:97-108.
SAS Institute Inc. 1996. SAS User's guide: Statistics. Version 6.12. SAS Instit. Inc., Cary, N.C.

Schimel, D.S. 1986. Carbon and nitrogen turnover in adjacent grassland and cropland ecosystems. Biogeochem. 2:345-357.

Tiwari, S.C., B.K. Tiwari, and R.R. Mishra. 1988. Enzyme activities in soils: effects of leaching, ignition, autoclaving and fumigation. Soil Biol. Biochem. 20:583-585.

Tomkins, I.B., J.D. Kellas, K.G. Tolhurst, and D.A. Oswin. 1991. Effects of fire intensity on soil chemistry in a Eucalypt forest. Aust. J. Soil Res. 29:25-47.

Ulery, A.E., R.C. Graham, and C. Amrhein. 1993. Wood-ash composition and soil $\mathrm{pH}$ following intense burning. Soil Sci. 156:358-364.

Voroney, R.P. and E.A. Paul. 1984. Determination of $\mathrm{Kc}$ and $\mathrm{Kn}$ in situ for calibration of the chloroform fumigation-incubation method. Soil Biol. Biochem. 16:9-14.

Walkley, A. and I.A. Black. 1934. An examination of Degtjareff method for determining soil organic matter and a proposed modification of the chromic acid titration method. Soil Sci. 37:29-37.

Wright, H. A. and A. W. Bailey. 1982. Fire ecology, United States and Southern Canada. John Wiley and Sons, New York.

Zuberer, D. A. 1994. Recovery and enumeration of viable bacteria. p.119-144. In R.W. Weaver et al. (ed.) Methods of soil analysis. Part 2- Microbiological and biochemistry properties. SSSA Book Series 5, Madison, Wisc. 